\title{
Implementing Industry 4.0 through Cleaner Production and Social Stakeholders: Holistic and Sustainable Model
}

\author{
Walter Cardoso Satyro ${ }^{1, *(\mathbb{D})}$, Jose Celso Contador ${ }^{2}$, Jose Luiz Contador ${ }^{3}$, Marco Aurélio Fragomeni ${ }^{2}$, \\ Sonia Francisca de Paula Monken ${ }^{4}$, Ana Freitas Ribeiro ${ }^{5,6}$, Anderson Ferreira de Lima 1(D), Jansen Anderson Gomes ${ }^{1}$, \\ José Roberto do Nascimento ${ }^{1}{ }^{\mathbb{D}}$, Josiane Lima de Araújo ${ }^{1}$, Rogério Glaser Prado ${ }^{1}$, Gilberto Gomes Soares Junior ${ }^{1}$ \\ and Victor Henrique Martins de Souza ${ }^{1}$
}

1 Postgraduate Program in Production Engineering, Campus Vergueiro, Nove de Julho University (UNINOVE), São Paulo 01525-000, SP, Brazil; andersonsp129@gmail.com (A.F.d.L.); jagomes@br.gestamp.com (J.A.G.); betojrn@yahoo.com.br (J.R.d.N.); josianelima.jna@gmail.com (J.L.d.A.); glasereglaser@uol.com.br (R.G.P.); gibertojrengenharia@gmail.com (G.G.S.J.); vhmsouza@gmail.com (V.H.M.d.S.)

2 Postgraduate Program in Administration, Campus Bacelar, Paulista University (UNIP), São Paulo 04026-002, SP, Brazil; celsocontador@terra.com.br (J.C.C.); patilipanda@yahoo.it (M.A.F.)

3 Engineering College, State University of São Paulo, Julio de Mesquita Filho (UNESP-Guaratingueta), São Paulo 01049-010, SP, Brazil; jluiz@feg.unesp.br

check for

updates

Citation: Satyro, W.C.; Contador, J.C.; Contador, J.L.; Fragomeni, M.A.; Monken, S.F.d.P.; Ribeiro, A.F.;

de Lima, A.F.; Gomes, J.A.;

do Nascimento, J.R.; de Araújo, J.L.; et al. Implementing Industry 4.0 through Cleaner Production and Social Stakeholders: Holistic and Sustainable Model. Sustainability 2021, 13, 12479. https://doi.org/ $10.3390 /$ su132212479

Academic Editors: Geraldo Cardoso de Oliveira Neto, Wagner

Cezar Lucato, Marlene Amorim and Vikas Kumar

Received: 3 October 2021

Accepted: 24 October 2021

Published: 12 November 2021

Publisher's Note: MDPI stays neutral with regard to jurisdictional claims in published maps and institutional affiliations.

Copyright: (c) 2021 by the authors. Licensee MDPI, Basel, Switzerland. This article is an open access article distributed under the terms and conditions of the Creative Commons Attribution (CC BY) license (https:/ / creativecommons.org/licenses/by/ $4.0 /)$.
4 Faculty of Public Health, University of São Paulo (USP), São Paulo 05508-220, SP, Brazil; sfmonken@gmail.com

5 Postgraduate Program in Science, Campus Vergueiro, Nove de Julho University (UNINOVE), São Paulo 01525-000, SP, Brazil; anafribeiro9@uni9.pro.br

6 Disease Control Coordination of the São Paulo State Health Department, Emílio Ribas Infectology Institute, São Paulo 01246-900, SP, Brazil

* Correspondence: satyro.walter@gmail.com

\begin{abstract}
Although Industry 4.0 has received much attention in recent years due to the possibility of increasing companies' productivity, the implementation process is complex. The aim of this study is to present a holistic model for implementing Industry 4.0 based on cleaner production as a fundamental tool for the development of production systems that meet the Sustainable Development 04026-002Goals (SDGs), and social stakeholders that cooperate with this implementation process, helping to develop sustainable infrastructure, processes and technologies to increase the sustainable transformation of these companies towards Industry 4.0. The method used was literature research, and the Delphi technique was used to ask specialists to contribute with their experience to evaluate and propose improvements to the model, in the form of a consensus. The model contributes to the Sustainable Development Goals 9, 12 and 15. This holistic and sustainable model is a contribution to theory and practice, helping executives, technicians, entrepreneurs and those involved with Industry 4.0 to base the implementation process in the needs and specificities of each company, avoiding the "one fits all" models, considering the peculiarities of each company and the complexity of the implementation process in a more efficient and collaborative digital production ecosystems base, seeking to reduce inequalities, through the joint effort of social stakeholders to find ways to restore and/or improve social harmony, impacted by Industry 4.0 .
\end{abstract}

Keywords: cleaner production; sustainability; goals of sustainable development; circular economy; stakeholder influences; sustainable development; implementation; Industry 4.0

\section{Introduction}

New digital technologies have enabled unprecedented interconnectivity, so that industries, supply chain, customers and other key stakeholders can be connected and integrated, enabling humans and machines to exchange data, opening new perspectives for industries [1-3]. This digital transformation, called the fourth industrial revolution, or Industry 4.0, is characterized by a new cycle of technological development [4] due to its 
potential to increase productivity. Despite its importance, the implementation process has received relative attention, but most are not concerned with cleaner production.

Cleaner Production (CP) can be understood as the use of preventive environmental strategies to services, products and processes to cooperate with the preservation of energy, water and raw materials, eliminating or reducing toxic materials, emissions and residues in the production process [5,6] or in the life cycle of a service or product [7]. The aim is to mitigate the risks to environment and people, increasing efficiency and, at the same time, bringing environmental and economic gains [5,8-11], when, at times, barriers will need to be broken in order to adopt cleaner production [10].

The adoption of cleaner production principles is a basic tool for the development of production systems that can achieve the Sustainable Development Goals (SDG) [12-14]. The seventeen SDGs were identified in the United Nations Agenda 2030, presented in 2015 and subscribed to by all United Nations countries, with the purpose of promoting justice, peace, prosperity, and minimizing inequalities, poverty and environmental and climatic deterioration [5,15-17].

Industry 4.0 is associated with a group of complex digital technologies to be used in the manufacturing system [18-20], and through the implementation of these technological solutions, productivity will be improved, and quality, reliability and costs will be optimized, among others [21-23]. The implementation process of Industry 4.0 involves opportunities, but also challenges, such as the strategic alignment of the organization, resistance of the organizational culture, lack of standardization, data security and high initial investment [24-27]. This involves assuming high risks, with possible impacts on financial institutions, and others [28].

The Industry 4.0 implementation process is complex and subject to some research [29-31]. Some relevant studies have proposed models to assess the readiness of manufacturing companies to implement Industry 4.0 [32-35]; other studies have proposed maturity models with the same purpose [36-39].

Implementing Industry 4.0 is a challenging process, as the models presented by academia and other institutions are hardly universally accepted, making it difficult for managers to follow a methodology for its implementation [25,40,41]. Strategic roadmaps to guide the process of implementing Industry 4.0 concepts/technologies are not yet clear in academia and industry $[21,42,43]$.

Studies that propose models to achieve cleaner production through implementing Industry 4.0 are scarce [44]. A mixed-integer linear programing model (MILP) was designed to reach cleaner production and circular economy, by optimizing machine-products allocation in Industry 4.0 [45]. In a model to assess Industry 4.0 implementation, technical capability was identified as the most relevant enabler for the adoption of sustainable development and cleaner production [46]. Industry 4.0 was combined with green and lean manufacturing in an implementation model with six phases and twenty-seven steps for improving environmental and economic performance [44]. A model was developed to reduce energy costs in intensive energy industries users during the implementation of Industry 4.0 [47].

The few studies found in the literature that take into account cleaner production for the implementation of Industry 4.0 do not consider the social stakeholders in this implementation process, which is a gap that this study seeks to address to the theory on Industry 4.0 production paradigm. In order to fill this gap, the following research questions were formulated:

RQ1: How should an Industry 4.0 implementation model look like to take into account cleaner production and social stakeholders?

RQ2: What Sustainable Development Goals this model can reach?

The objective of this study is to contribute to the formulation of theory on Industry 4.0, presenting a holistic model for implementing Industry 4.0 based on cleaner production and social stakeholders that cooperate with this implementation process, helping to preserve jobs (people) and develop an adequate infrastructure, processes and technologies to 
increase sustainable transformation of these companies towards Industry 4.0, and evaluate the contributions to the Sustainable Development Goals.

\section{Literature Review}

\subsection{Industry 4.0}

Although some studies question whether the evolution of industry occurred by natural technological evolution or revolutions $[33,48,49]$, four industrial revolutions are usually cited.

The use of water and steam power made possible the mechanization of manufacturing by 1760 , which is called Industry 1.0 or the first industrial revolution, bringing new levels of productivity and reducing the use of human physical strength [50,51]. Electrical power and job division made possible mass production through the use of assembly lines, considered as Industry 2.0 or the second industrial revolution [52,53]. In 1969, with the launch of the first Programmable Logic Control (PLC) and the use of electronics, computing, and telecommunications, made possible automation and robotics in operation lines, when Industry 3.0 or the third industrial revolution arrived [54,55].

The world is increasingly uncertain and complex, and industries need to quickly adapt to the market to prevent loss of market share and survive in this challenging scenario [56-58]. To help industries overcome this situation, Industry 4.0 was launched. Figure 1 illustrates the four industrial revolutions.

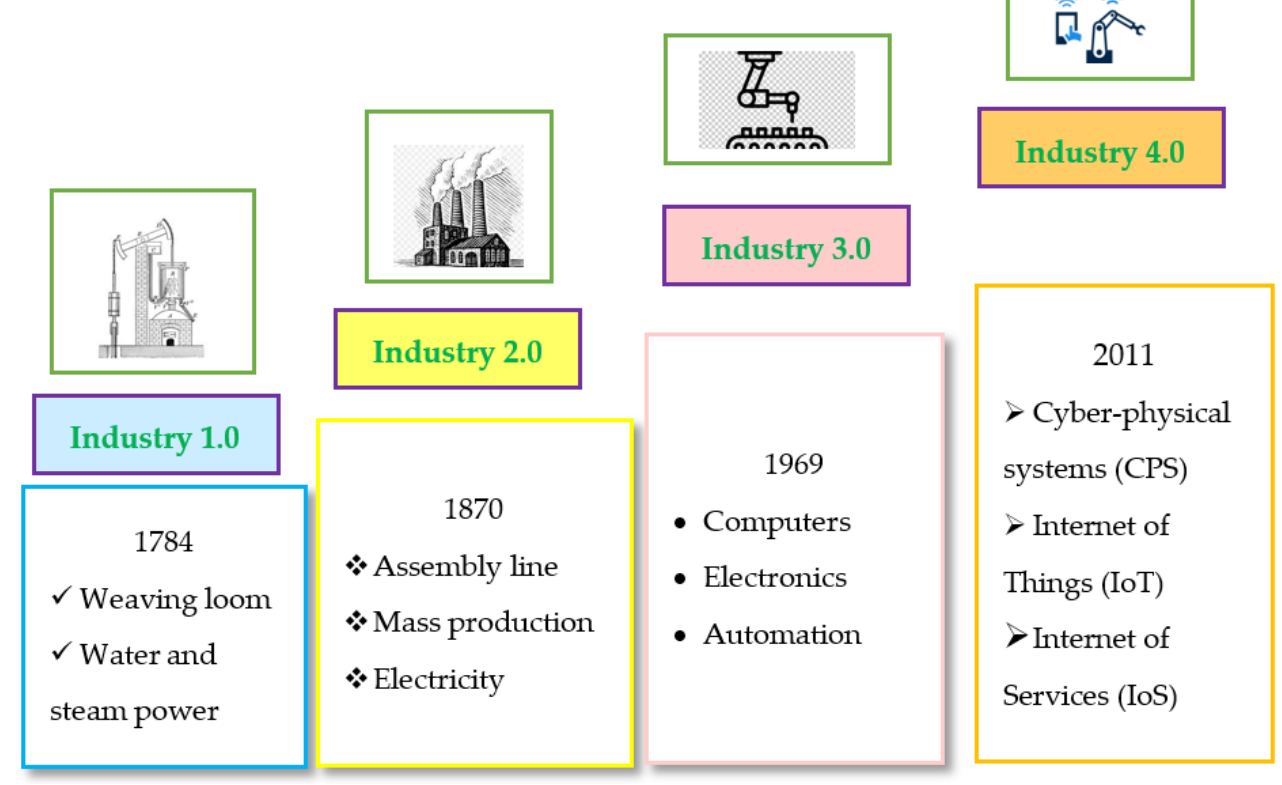

Figure 1. The four industrial revolutions.

The term Industry 4.0 was coined at Hanover Fair, 2011, as part of a German Government program to improve the competitiveness of their companies, based on high technology, having for pillars: Cyber-physical Systems (CPS), Internet of Services (IoS) and Internet of Things (IoT) [2,59,60].

\subsection{Industry 4.0 and Flexibility}

Industry 4.0 encompasses technology-based concepts, with the potential to improve performance [61], increase quality, and enable mass customization, bringing more production flexibility than conventional manufacturing $[33,62,63]$.

This industrial paradigm is based on the convergence between Production Systems, Automation Technology (AT) and Information Technology (IT), which enables digital interconnectivity, enabling the exchange of data and information between machines, devices, suppliers, customers and relevant stakeholders [64-66]. 
Given the wide possibilities of Industry 4.0, other nations have also formulated programs with similar objectives to those of Germany, such as: Made-in-China 2025 in China [67], Industrial Internet Consortium in the USA and Manufacturing Industry Innovation 3.0 strategy in South Korea.

\subsection{Cleaner Production}

Due to the high level of consumption by the population, the continual expansion of the industrial production to meet this consumption and the problem of environmental degradation, the United Nations Environment Programme (UNEP) [68] was created in 1972 to organize international initiatives for environmental protection and the promotion of sustainable development [69].

Cleaner production is defined as a preventive and integrated strategy applied to products, processes and services to improve efficiency and reduce risks to humans and the environment [68], such as the use of sustainable raw materials and the practice of recycling throughout the processes, among others.

Figure 2 displays a strategic model of the Cleaner Production, presenting its many possibilities to increase industrial performance and, at the same time, protect the environment $[68,69]$, showing industrial areas for improvement: product modification, good housekeeping, input material change, production of useful by-products, better process control, on-site recovery/reuse, technology change, equipment modification [69].

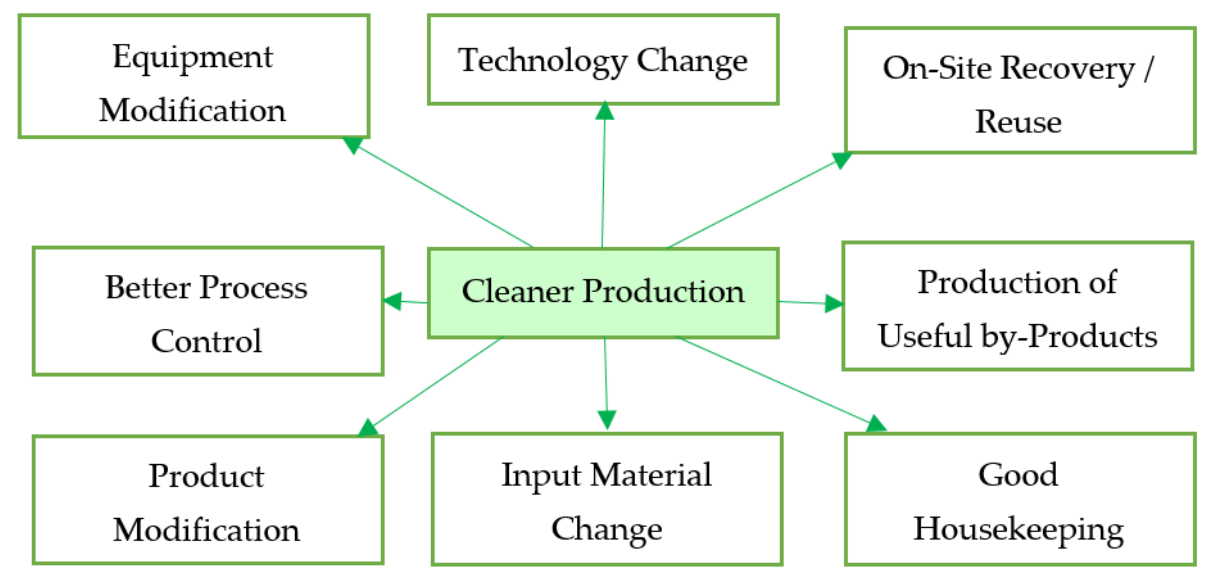

Figure 2. Strategic model of the Cleaner Production. Adapted from [70].

\subsection{Sustainable Development Goals (SDGs)}

Concerned with inequalities and built on the concept of Sustainable Development as a development that meets current needs without harming the potential of future generations, in September 2015 the United Nations General Assembly adopted the 2030 Agenda for Sustainable Development composed of 17 Sustainable Development Goals (SDGs) [70-72], subscribed to by all the United Nations countries.

The concept is to overcome the global challenges we face today. The 17 Goals are linked together, but achieving these goals in 2030 seems a very ambitious goal, almost impossible given what we have today.

Each SDG have specific targets, addressing a wide range of issues, including climate change and environmental degradation. Figure 3 displays the 17 SDGs.

Table 1 presents the 17 Goals and a brief description of each Sustainable Development Goal. 


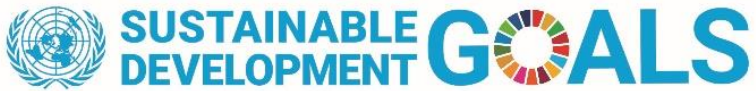
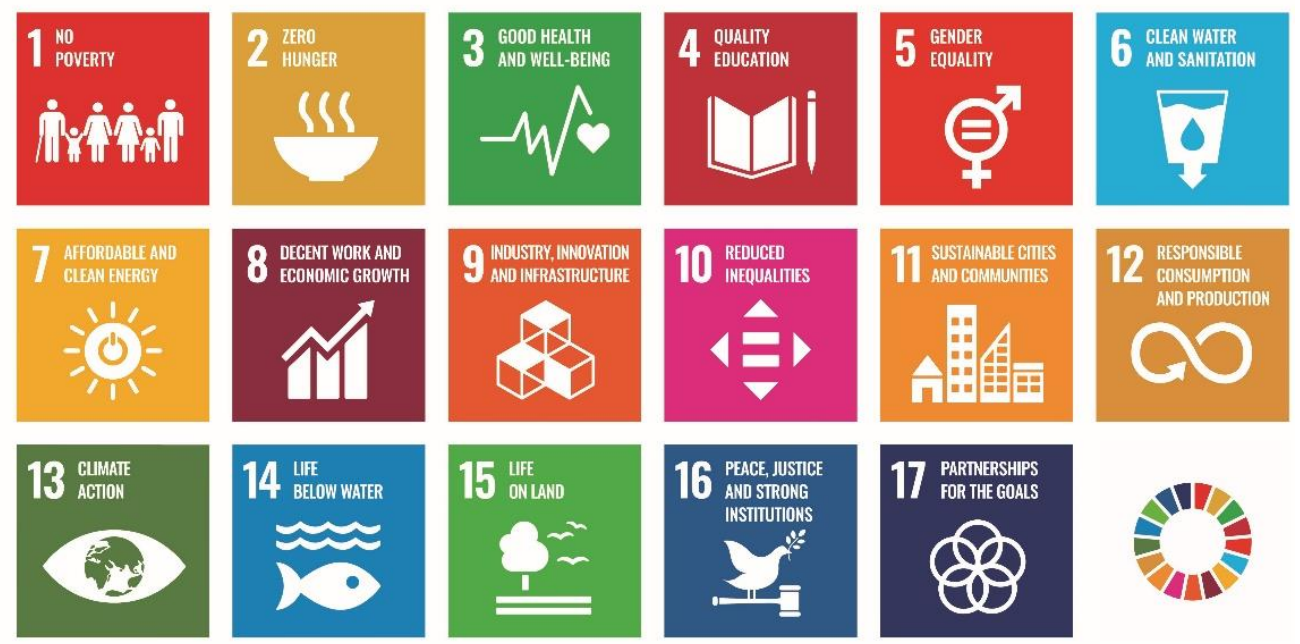

Figure 3. The 17 Sustainable Development Goals. Source [70].

Table 1. Brief description of each Sustainable Development Goal.

\section{Goal}

\# 1 No poverty

\# 2 Zero Hunger

\# 3 Good health and well-being

\# 4 Quality education

\# 5 Gender equality

\# 6 Clean water and sanitation

\# 7 Affordable and clean energy

\# 8 Decent work and economic growth

\# 9 Industry, innovation and infrastructure

\# 10 Reduced inequalities

\# 11 Sustainable cities and communities

\section{Description}

It is estimated that around $10 \%$ of the world population, or 790 million people (2021), live in extreme difficulties, struggling to fulfil needs like food, education, health and access to sanitation and water. The COVID-19 pandemic could lead an additional 71 million people to this condition.

In 2019 , about $25 \%$ of the world population (around 2 billion people) did not have access to sufficient and nutritious food. Food scarcity and high food prices are world problems, mainly in Africa and Asia.

Poor countries did not have sufficient health facilities. The COVID-19 pandemic aggravated this situation. An additional 18 million health workers are needed in poor countries.

Education is a key to escaping poverty, reducing inequalities. Around 773 million adults remained illiterate in terms of writing and reading skills.

Gender inequality remains everywhere, stagnating social development. Only $28 \%$ of the managerial positions worldwide were held by women.

Water is necessary for health, as well as to food security, poverty reduction, human rights, education and peace. Around 785 million people do not have basic drinking water.

Energy system is basic to support all sectors of the economy, such as: medicine, education, agriculture, infrastructure, etc. Around the world, about 789 million people do not have access to electricity.

Inclusive and sustainable economic growth creates jobs, drives progress and raises living standards. The COVID-19 pandemic is negatively impacting the economy, generating unemployment.

Industrialization brings opportunities to all; resilient infrastructure and innovation support it. In total, $54 \%$ of the world's population uses the Internet, but in poor countries only $19 \%$ of the population can access it.

Two out of 10 people have suffered discrimination. Inequality is growing around the world, increasing the risk of wars and making it harder to promote social and economic development.

Nine out of 10 people live in urban areas around the world. It is fundamental that cities can provide adequate infrastructure, services and planned urban development, and at the same time sustainable. 
Table 1. Cont.

\begin{tabular}{|c|c|}
\hline Goal & Description \\
\hline $\begin{array}{l}\text { \# } 12 \text { Responsible consumption } \\
\text { and production }\end{array}$ & $\begin{array}{l}\text { It is important to reach sustainable consumption of products to keep social and economic } \\
\text { progress, avoiding environmental degradation that can compromise the future } \\
\text { development of the next generations. }\end{array}$ \\
\hline \# 13 Climate action & $\begin{array}{c}\text { Every country in the world is being affected by climate change, bringing droughts, wildfires, } \\
\text { floods, hurricanes and other climate disasters. }\end{array}$ \\
\hline \# 14 Life below water & $\begin{array}{l}\text { Fisheries and the oceans supply the social, environmental and economic needs of the global } \\
\text { population. About } 3 \text { billion people depend on coastal and marine biodiversity for their } \\
\text { financial support. }\end{array}$ \\
\hline \# 15 Life on land & $\begin{array}{l}\text { In total, } 31 \% \text { of our planet's land area is covered by forests. Degradation compromises } \\
\text { species, promotes climate change and harms the livelihoods of } 3.2 \text { billion people. }\end{array}$ \\
\hline $\begin{array}{l}\text { \# } 16 \text { Peace, justice and } \\
\text { strong institutions }\end{array}$ & $\begin{array}{l}\text { Sustainable development needs to be based on an inclusive and peaceful society, providing } \\
\text { access to justice for all. Everyday } 100 \text { civilians are killed in armed conflicts. } \\
\text { To solve the world problem, it is necessary to strengthen the global partnership and }\end{array}$ \\
\hline \#17 Partnerships for the goals & $\begin{array}{l}\text { multilateralism. It is time for governments, scientists, civil society, academia and the private } \\
\text { sector to unite for the common good. }\end{array}$ \\
\hline
\end{tabular}

\section{Materials and Methods}

As it was not possible to find in the literature a model that could take into account cleaner production and social stakeholders to help increase the sustainable transformation of companies towards the implementation of Industry 4.0 and, at the same time, achieve relevant Sustainable Development Goals, a literature review was used as the basis for the development of the model.

The initial model was presented to two Production Engineering Professors, each with more than 20 years of experience in teaching and research, for validation, to ensure that the findings are relevant to achieving the objectives. They made minimal changes to the model, which were incorporated into the first model to be presented to specialists.

The Delphi technique was used to ask specialists to evaluate the model. The Delphi technique is an interactive and systematic research technique to gather the consensus of opinion of a group of specialists on a specific subject [73].

Five specialists were invited to evaluate the proposed model and the consensus among specialists was reached in a two-round Delphi survey. These specialists were strategically invited to participate, as they have more than 10 years of experience and are involved in the process of implementing Industry 4.0 in their companies.

To assess the relevance and rarity of the study, the Scopus and Web of Science database were used, as presented in Table 2.

Table 2. Number of documents in Scopus and Web of Science database.

\begin{tabular}{lcc}
\hline Search String & Scopus & Web of Science \\
\hline “Industry 4.0" & 15,566 & 8933 \\
"Industry 4.0" AND implement* & 4364 & 2679 \\
"Industry 4.0" AND implement* AND (model OR framework) & 1970 & 1480 \\
"Industry 4.0" AND implement* AND (model OR framework) & 5 & 4 \\
AND “cleaner production" & & \\
\hline
\end{tabular}

The search was performed in June 2021, using the search string in the Title, Abstract or Keywords, displayed in Table 2. The numbers represent the quantity of documents (papers, conference papers, books, book chapters, reviews, and conference reviews) presented in each database, the year of publication was left open and no filter was used.

Analyzing Table 2, the process of implementing Industry 4.0 has aroused the interest of many studies, as $28 \%$ of the studies of Industry 4.0 are about implementation. The proposition of models or models constitutes the majority of these studies $(45 \%)$, but analyzing them from the perspective of cleaner production constitutes a rarity of studies. 
The 4 documents found in Web of Science database were duplicated in Scopus, so the number of documents, in this case, papers, was 5 in total, from 1970 documents.

\section{Results and Discussion}

Like other industrial revolutions, Industry 4.0 is expected to have a broad impact on industries, markets and society in general.

\subsection{Opportunities}

It is expected that the implementation of the concepts of Industry 4.0 will bring great opportunities, such as: (1) Provide better production and planning control, through the integration of technologies and communication between customers, suppliers, production and other relevant stakeholders, (2) Increase the company's global competitiveness, (3) Become or be seen as a modern company, (4) Improve the quality of the production lines, (5) Become or be seen as a company that provides products with superior performance, (6) Reach a better customer/business interaction (pre-sales/sales/after-sales), (7) Increase market share, (8) Deliver products in less time than competitors, (9) Become or be seen as a trustworthy company, (10) Delivery within the initial forecast [18,74-78].

\subsection{Barriers}

Although the barriers to the implementation of the concepts of Industry 4.0 are relevant, it seems to be less addressed in academic studies [76].

Specialists recognize in the implementation of Industry 4.0 concepts a great opportunity to develop and improve competitiveness [74], but the implementation of the concepts of Industry 4.0 requires high investments in advanced technologies and the integration of these technologies.

Here follows some barriers found in scientific papers: (1) Need to improve the company's infrastructure, (2) High investments for implementation, (3) Difficulty in changing the organizational culture, (4) Necessity of new management skills, (5) Difficulty in establishing an investment program/Return on Investments (ROI), (6) Difficulty in accessing the learning of new management techniques to organize a company, (7) Difficulty in hiring/training people in digital technology, (8) Leadership resistance to the implementation, (9) Difficulty in integrating information systems, (10) Lack of examples that can be followed for the implementation process $[75,76,79]$.

\subsection{Implementing Industry 4.0}

To analyze relevant models/models of implementing Industry 4.0 in the academic literature, which addressed several different perspectives other than cleaner production, the following string of research was used: "Industry 4.0" AND implement* AND (model OR model), resulting in 1970 documents in Scopus and 1480 in Web of Science. To filter these documents, the research was limited to: English language, papers, and subject area: Engineering and Business, Management and Accounting, resulting in 117 papers that had their abstracts read, with 42 papers selected for full reading. Only six papers presented some sort of model, from different perspectives, showing the rarity of the theme.

This may be due to the fact that despite the interest in Industry 4.0, evidence of its implementation in practice is still rare [76], challenging and risky, given the need for major systemic transformations that are required in this paradigm shift [80], hindering the work of researchers, entrepreneurs, executives, managers and everyone involved in the process of implementing Industry 4.0.

Industry 4.0 significantly changes production systems and products, with respect to the operations, services and design process [74].

The implementation of the concepts of Industry 4.0 brings consequences for the management and creation of new jobs generating new business models. This impacts industries and markets, contributing to new ways of producing and running a business, while allowing for process improvements and increasing the competitiveness of companies. [74]. 
The implementation process varies greatly, depending on the country, sector of economy or even from one company to another [74].

\subsubsection{General Approaches}

Few Industry 4.0 implementation models have been proposed under different approaches:

(1) Sjödin et al. [80] developed a model based on (i) People — to create and maintain a digital culture associated with innovation, (ii) Process-to establish agile processes, based on data, and (iii) Technology - to configure modular technology to manage the complexity of digital systems, introducing systems to view and monitor critical operational analytics and integrate them with relevant stakeholders;

(2) Mueller et al. [81] created a model considering: (i) Manufacturing process-controlled in real time, (ii) Devices-physical devices that automatically connect to the information system, (iii) Software-to control business management, production management, regulation and control and other software and (iv) Engineering - to analyze the need for resources in terms of human resources and machinery;

(3) Martinez [82] generated a model that considers the following steps (i) Define operational efficiency and (ii) understand customer orientation, (iii) analyze the operation, (iv) develop technological solutions, (v) implement solutions and (vi) integrate them, (vii) review, (viii) adjust and (ix) improve the solutions.

(4) Devi et al. [83] designed a model in which the implementation process was based on high level management that encourages the supply chain and the horizontal and vertical integration, then, use big data, Internet of Things (IoT), and Visual computing to lean on Cyber Physical Systems, which provides the basis for new technologies, as well as management and training systems to reach new steps for the implementation of Industry 4.0.

(5) Rybski and Jochem [84]) developed a model based on companies that have already implemented lean manufacturing. The process is divided into four phases: (i) Planning process-Goals, pilot areas, roles and responsibilities are defined, budget planning and the qualification of the workforce is established; (ii) Technical preparation-Qualify experts and technology, qualify skills; (iii) Pilot implementation-Implement one or two technologies in pilot areas, create knowledge; (iv) Control and improvement-Control project, transfer acquired knowledge to other areas.

(6) In a model created by Krishnan et al. [18], the basis is the interest of top managers in implementing Industry 4.0. This process must be supported by Government policies to guarantee the financial performance of industries. Digital processes must be integrated, and the innovativeness of the company to provide a global competitive advantage must be developed in order to satisfy society's expectation. Thus, industries will be able to adopt Industry 4.0, enabling the fulfillment of customized orders and facing environmental challenges.

The manufacturing sector still has doubts about the implementation of Industry 4.0 [85], since the adoption of Industry 4.0 is still in its initial phase, with many challenges to be overcome [86].

\subsubsection{Cleaner Production Approaches}

Some studies have analyzed the implementation of Industry 4.0 from the perspective of cleaner production.

(1) Amjad et al. [44] developed a model combining lean green manufacturing, lean manufacturing and Industry 4.0 to eliminate waste and optimize production. The model starts with the identification of the industry's problems and introduces the Lean production philosophy. After Lean manufacturing is completely implemented, Cyberphysical systems and controls are introduced as the beginning of the implementation of the Industry 4.0 paradigm. After this stage, the concepts of Green Manufacturing are introduced under the commitment of top senior executives, with the implementation of ISO 14001, 6R techniques (reuse, reduce, recycle, recover, redesign and 
remanufacture) to reduce energy consumption, greenhouse gases (GHG) emissions and resource usage, and use of renewable energy resources. The model emphasizes the reach of smart energy monitoring using Industry 4.0 concepts.

(2) The model proposed by Shayganmehr et al. [46], considered Industry 4.0 as a key instrument to support the implementation of the Circular Economy (CE) and Cleaner Production (CP) to increase the quality of services and products in a context of sustainable and ethical business development. The model is a readiness model for the implementation of Industry 4.0 with six enablers: (i) Technical capability; (ii) Policy and regulation; (iii) Education and participation; (iv) Security and safety; (v) System flexibility; and (vi) Support and maintenance, and sub-capacitors. Technical capability was considered the most important enabler to successfully adopt sustainable development and cleaner production.

(3) Rajput and Singh [45] developed a model to minimize machine processing costs and energy consumption through effective machine-product allocation, to reach cleaner production and circular economy by reducing energy consumption.

(4) The model developed by Ma et al. [47] aims to save energy costs, based on plant, machinery and shop-floor, through the technologies of Industry 4.0. There are three layers in the model: (i) Perception layer-Energy consumption was monitored in realtime, (ii) Management layer-for energy efficiency assessment, and (iii) Application service layer-for energy efficiency optimization. The model foresees external links with the Government and energy departments.

(5) Lu et al. [87], suggested that industries should consider in their business strategy, from the initial phase of implementing Industry 4.0, that in all decisions, policies, actions and practices, the following components should be analyzed: environmental, philanthropic, legal, ethical and economical. This reinforces the role of corporate social responsibility and organizational innovation in contributing to organizational performance [88], which is relevant to the adoption of an environmentally sustainable manufacturing.

The strengths of some models are basing the process on industry needs, involving top executives and adapting the organizational culture to the introduction of different production systems. Others consider the circular economy and cleaner production as pillars for the implementation of Industry 4.0 and easy to handle. There are models that focus on reducing investments in machinery and energy consumption, one of the main challenges in implementing Industry 4.0, and others focus on minimizing energy consumption and strengthening ties with Governments and the energy department. Another considers the social aspects, is concerned with providing guidance to support the business strategy, and can be applied in any situation, not just in the implementation of Industry 4.0.

The weakness of some models is the time required for this implementation to base the implementation process on Lean manufacturing, and only later for the Green Manufacturing implementation. The introduction of Cyber-physical systems, controls and energy monitoring does not guarantee the implementation of the Industry 4.0 paradigm. The social impact of Industry 4.0 implementation was not discussed in some models. In addition to a readiness model, it is restricted to analyzing an industry moment. Some models are restricted in scope and others are too generic to provide guidance.

\subsection{The Proposed Model}

The proposed model is presented in Figure 4.

The proposed model is centered on the cleaner production strategy, considered a fundamental tool for the development of production systems that meet the Sustainable Development Goals (SDGs), and on social stakeholders, as a basis for the implementation process, and not as a consequence of this implementation, as seen in some approaches.

The model shows the need for an integrated and participatory approach for the implementation of Industry 4.0, presenting the flow of processes that interact with each other, described below. It is designed to present a holistic view of the complexity surrounding 
the implementation of Industry 4.0, going beyond the purely technology-centric approach that has dominated academic studies, but considering the relevance of technology.

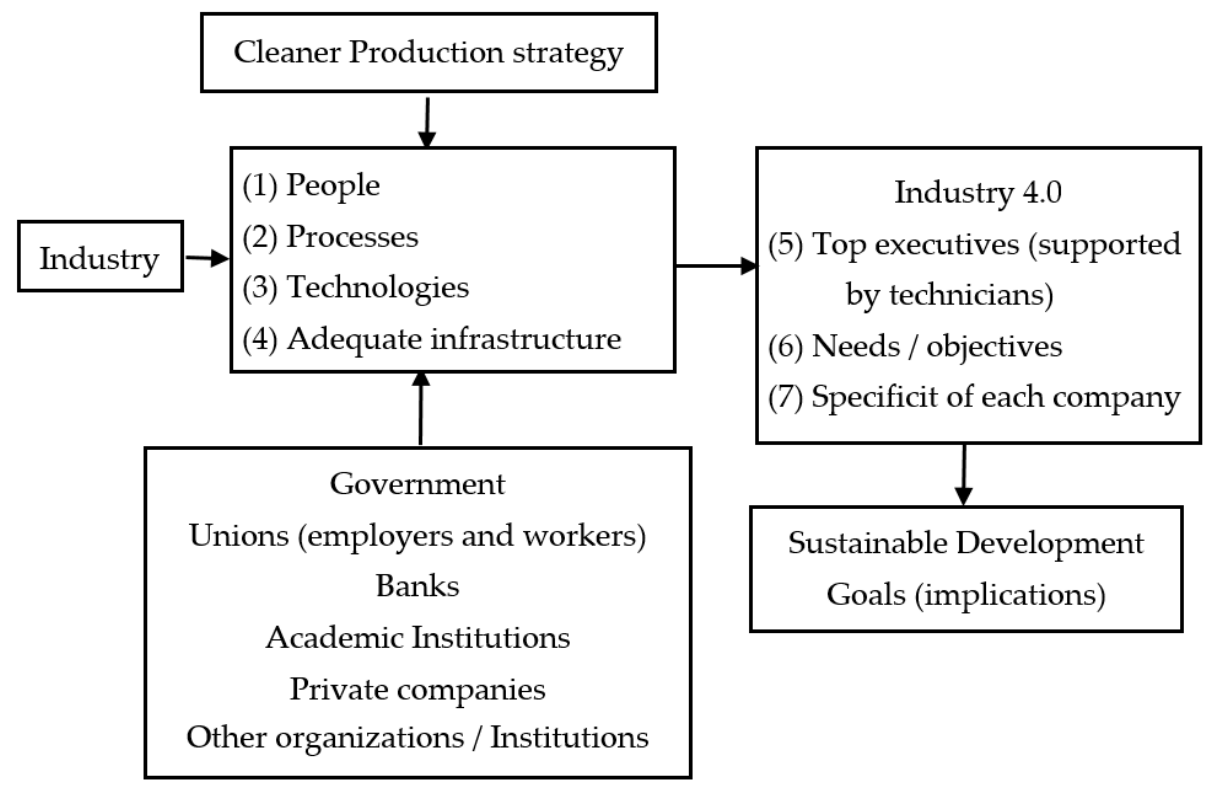

Figure 4. Proposed model.

Due to the importance of preserving the environment, cleaner production should be considered a fundamental need, as a basis, from the initial stages of the implementation of Industry 4.0 [44-47], and not as a result of the implementation process.

The fundamental concept of this model is to base the Industry 4.0 implementation process using cleaner production as a strategic tool. From the beginning, the technologies and concepts of Industry 4.0 must be established based on the preservation of water, energy, raw material, reduction or elimination of emissions, toxic material and residues in the production process $[5,6,44-47]$ or in the life cycle of a product or service $[7,89,90]$. The objective is to bring environmental and economic gains, while increasing efficiency and reducing risks to the environment and people [5,8-12,44-47].

(1) People must be a relevant factor of attention. The implementation of Industry 4.0 is complex, involves extensive capital and time to train the workforce, adapt the organization's culture, and install, integrate and operate the new (2) processes and (3) technologies [74-76,79,91-93].

It is a technological and organizational culture change that involves risks, which grow as companies find themselves in advanced technological stages [75,76,79,94]. Companies that are in the Industry 1.0 or 2.0 stage should consider introducing automation technology and information technology first into the production process to reach the Industry 3.0 standard first, in order to reduce investments, risks and prepare the organizational culture.

(4) Adequate infrastructure is necessary to support the complexity of the changes, requiring that companies can be guided in this implementation process. It is expected that the implementation of Industry 4.0 will bring unemployment [74-79] to the less qualified workforce, so these companies should be oriented towards alternatives to preserve the income and/or employment of this less favored workforce, reducing inequalities [74-79]. It is suggested that social stakeholders such as: Government $[95,96]$, unions (employers and workers), banks, academic institutions, other organizations and institutions, as well as private companies $[18,47,72]$ can join efforts to assist in this process.

Unions, academic institutions, and other organizations and institutions engaged in the process, should seek alternatives for the possible unemployed [97], such as training, requalification, entrepreneurship, among other alternatives.

Governments must establish public policies to provide an adequate infrastructure, finance and encourage this implementation [18]. Banks should offer prime rate credit lines to encourage this process. 
From the adoption of a Cleaner Production strategy, organizations, institutions, academic institutions and private companies, even though they are competitors, must jointly analyze the best alternatives to overcome the barriers and take advantage of the opportunities of this implementation process, helping in the development of sustainable processes, infrastructure, and technologies to increase the sustainable transformation of these companies towards Industry 4.0.

In the companies the process must be conducted by (5) top executives, supported by qualified and committed technicians, as it involves substantial changes, requiring leaders who can move forward, correct directions and maintain the necessary change actions to minimize risks, keep investments within budget and keep everyone involved in this process of change and open to innovation $[19,84]$.

The (6) needs and objectives of each company must be established from the beginning to propel the company on this journey to Industry 4.0. That is, companies should implement Industry 4.0 in an effort to achieve their goals [84], not by fad or impulse.

Considering that the implementation process varies a lot, depending on the country [73], and that companies, even in the same economic sector, have their (7) own specificities, the model does not suggest the process of internal implementation in each company. This internal process must be built considering each goal or objective in partnership with academic institutions, organizations and institutions, private companies, and other relevant stakeholders. General guidelines can be suggested, but propose a general process of internal implementation, and to think that any company could adopt it is to disregard the differences between the companies.

The processes that make up the holistic model are networked, influencing and being influenced by other processes. Depending on the stage of the industry, the greater the investment effort in the implementation process will be, which is influenced by the determination of Governments to support their industries for the implementation of Industry 4.0, through different mechanisms and/or actions.

The holistic model presents the network where top executives are influenced in their decisions about the implementation of Industry 4.0 by the cleaner production strategies, associated with the ease of finding qualified labor, affordable technology prices, which will determine the manufacturing processes, as well as internal and external infrastructure of the environment of the company.

The joint determination of social stakeholders to generate industrial development through the use of cleaner production strategies while preserving sustainable development and social harmony, ends up connecting to generate a positive impact on the Sustainable Development Goals.

\subsection{Implications for the Sustainable Development Goals}

The model based on cleaner production and social stakeholders allows the implementation of Industry 4.0 with environmental advantages, enabling companies to meet the following SDGs:

\# 9 Industry, innovation and infrastructure-Industry 4.0 can make industries more productive, bringing opportunities to all, but it must be supported by a resilient infrastructure, hence the need for Government participation in the implementation process, under a culture of innovation.

\# 12 Responsible consumption and production-As the model is based on cleaner production to reach Sustainable Production Consumption, it is strategic to maintain economic and social development, avoiding environmental degradation, in order to keep the development of the future generations.

\# 15 Life on land-The cleaner production strategy adopted in this model is supposed to reduce degradation that compromises species and reduce climate change.

Manufacturing is an important sector of the economy that brings wealth where it is installed [98], so that some other SDGs can be indirectly reached by increasing the productivity and competitiveness of these companies, such as: \# 1 Reduce poverty, and \# 2 Hunger 
- increasing the populations' income; \# 3 Good health and well-being, by building or expanding health facilities and \# 4 Quality education demanded by a higher income population. \# 6 Clean water-companies can contribute by using cleaner production, which reduces water contamination and waste [99].

\subsection{Contributions to Theory}

This holistic and sustainable model contributes to the theory of implementation of Industry 4.0, presenting that (i) it is possible to migrate from any stage to Industry 4.0, but to reduce risk exposure and investments it is advisable that companies have at least adopted Automation and Information Technologies; (ii) Cleaner production should be considered a strategic factor to base the implementation process, not as a result of this process, bringing environmental and economic gains, furthermore increasing efficiency and reducing risks to environment and people [5,8-11]; (iii) Government, unions, banks, academic institutions, other organizations and institutions, as well as private companies, should join efforts by collaborating with this implementation process [18,47,72], helping to develop sustainable processes, infrastructure and technologies to increase sustainable transformation of these companies towards Industry 4.0; (iv) Due to the risks, complexity and volume of investments, the implementation process must be led by top executives supported by technicians [82,84]; (v) Needs and goals must be defined from the beginning to guide investments and the course of actions [84]; (vi) The peculiarities of each company must be considered before establishing an implementation process; (vii) The model directly contributes to the Sustainable Development Goals 9-Industry, innovation and infrastructure, 12-Responsible consumption and production, and 15-Life on land and, indirectly, to some others.

\subsection{Contributions to Practice}

The competition among industries has intensified, they need to stay competitive to remain in the global market, becoming more flexible to adapt to a tempestuous competitive environment to gain competitive advantage $[100,101]$.

The contribution to the practice is to alert entrepreneurs, technicians, executives and those involved with Industry 4.0 to base the implementation process in cleaner production, in order to promote operational, environmental and economic benefits [102,103] and in the needs and specificities of each company, avoiding general models, respecting the companies and the complexity of the implementation process, based on more efficient and collaborative digital production ecosystems.

\section{Conclusions}

The objective of this study is to present an implementation model of Industry 4.0. A holistic model for implementing Industry 4.0 was proposed, based on cleaner production as a fundamental tool for the development of production systems that meet the Sustainable Development Goals (SDGs) and social stakeholders considered pillars for this implementation process, helping to develop sustainable infrastructure [74-79], processes $[18,80]$ and technologies $[16-20,47,74-76,79,84]$ to increase the sustainable transformation of these companies towards Industry 4.0. The model was evaluated and improved by specialists through the Delphi technique.

The proposed model presents, in a holistic way, the complexity that represents the implementation of Industry 4.0 and its interrelated processes, being possible to provide implementation guidelines for companies of the industrial sector.

Unlike other industrial revolutions, the Fourth Industrial Revolution is being studied as it develops, providing an opportunity to seek to reduce inequalities, as generated by other industrial revolutions. The contribution of this model to society, in this sense, is to bring together different relevant social stakeholders (Government, unions, etc.) seeking to reduce negative impacts on society, such as unemployment, reduced income and other impacts on the Sustainable Development Goals, expected with Industry 4.0. 
Despite being a theoretical model, a limitation of this study, it is suggested that future studies use it in practice, so that its strengths can be evaluated and its weakness corrected.

Author Contributions: All authors contributed to the study design. Conceptualization: W.C.S., J.C.C., J.L.C. and M.A.F.; methodology: S.F.d.P.M., A.F.R., A.F.d.L., J.A.G., J.R.d.N., G.G.S.J. and R.G.P.; validation: J.L.d.A. and V.H.M.d.S.; writing-original draft preparation: W.C.S.; writing-review and editing: S.F.d.P.M., A.F.R. and J.C.C., visualization, J.L.C. and M.A.F.; supervision, W.C.S. and J.C.C.; project administration, S.F.d.P.M. and A.F.R.; funding acquisition, A.F.d.L., J.L.d.A. All authors have read and agreed to the published version of the manuscript.

Funding: This research was funded by the Coordination for the Improvement of Higher Education Personnel (CAPES) of the Federal Government of Brazil.

Institutional Review Board Statement: Not applicable.

Informed Consent Statement: Not applicable.

Acknowledgments: The authors acknowledge CAPES for the resources to make this research. The authors are grateful to Dinan Dhom Pimentel Satyro for the language review.

Conflicts of Interest: The authors declare no conflict of interest.

\section{References}

1. Kagermann, H.; Wahlster, H.; Helbig, J. Securing the Future of German Manufacturing Industry: Recommendations for Implementing the Strategic Initiative INDUSTRIE 4.0-Final Report of the Industrie 4.0 Working Group; Acatech: Munich, Germany, 2013 ; pp. 1-82.

2. Hermann, M.; Pentek, T.; Otto, B. Design principles for Industrie 4.0 scenarios. In Proceedings of the 201649 th Hawaii International Conference on System Sciences (HICSS), Koloa, HI, USA, 5-8 January 2016; pp. 3928-3937.

3. Satyro, W.C.; Sacomano, J.B.; da Silva, M.T.; Gonçalves, R.F.; Contador, J.C.; von Cieminski, G. Industry 4.0: Evolution of the Research at the APMS Conference. In Advances in Production Management Systems. The Path to Intelligent, Collaborative and Sustainable Manufacturing; Lödding, H., Riedel, R., Thoben, K.D., von Cieminski, G., Kiritsis, D., Eds.; Springer: Cham, Switzerland, 2017; Volume 513, pp. 39-47. [CrossRef]

4. Schwab, K. The Fourth Industrial Revolution, 1st ed.; Penguin Group: London, UK, 2017.

5. De Oliveira Neto, G.C.; Correia, J.M.F.; Silva, P.C.; Sanches, A.G.O.; Lucato, W.C. Cleaner Production in the textile industry and its relationship to sustainable development goals. J. Clean. Prod. 2019, 228, 1514-1525. [CrossRef]

6. De Oliveira Neto, G.C.; Cesar da Silva, P.; Tucci, H.N.P.; Amorim, M. Reuse of water and materials as a cleaner production practice in the textile industry contributing to blue economy. J. Clean. Prod. 2021, 305, 127075. [CrossRef]

7. Baas, L.W. Cleaner production: Beyond projects. J. Clean. Prod. 1995, 3, 55-59. [CrossRef]

8. De Oliveira Neto, G.C.; Shibao, F.Y.; Filho, M.G.; Chaves, L.E.C. Cleaner production: A study of the environmental and economic advantage in polymer recycling. Interciencia 2015, 40,364-373.

9. de Oliveira Neto, G.C.; Tucci, H.N.P.; Correia, J.M.F.; da Silva, P.C.; da Silva, D.; Amorim, M. Stakeholders' influences on the adoption of cleaner production practices: A survey of the textile industry. Sustain. Prod. Consum. 2021, 26, 126-145. [CrossRef]

10. Leite, R.; Amorim, M.; Rodrigues, M.; Oliveira Neto, G. Overcoming barriers for adopting cleaner production: A Case study in Brazilian small metal-mechanic companies. Sustainability 2019, 11, 4808. [CrossRef]

11. De Oliveira Neto, G.C.; Correia, J.M.F.; Tucci, H.N.P.; Da Silva, P.C.; Da Silva, D. Relationship between cleaner production practices and company size in the Brazilian textile industry. Environ. Eng. Manag. J. 2021, 20, 203-216. [CrossRef]

12. Gunarathne, N.; Sankalpani, U. Diffusion of cleaner production in a developing country: The case of Sri Lanka. J. Clean. Prod. 2021, 311, 127626. [CrossRef]

13. Santos, V.; Gomes, S.; Nogueira, M. Sustainable packaging: Does eating organic really make a difference on product-packaging interaction? J. Clean. Prod. 2021, 304, 127066. [CrossRef]

14. Ilyas, S.; Kim, H.; Srivastava, R.R.; Choi, S. Cleaner production of rare earth elements from phosphorus-bearing sulfuric acid solution of vein deposit monazite. J. Clean. Prod. 2021, 278, 123435. [CrossRef]

15. Munguia, N.; Esquer, J.; Guzman, H.; Herrera, J.; Gutierrez-Ruelas, J.; Velazquez, L. Energy efficiency in public buildings: A step toward the UN 2030 Agenda for Sustainable Development. Sustainability 2020, 12, 1212. [CrossRef]

16. Mhlanga, D. Artificial intelligence in the industry 4.0, and its impact on poverty, innovation, infrastructure development, and the sustainable development goals: Lessons from emerging economies? Sustainability 2021, 13, 5788. [CrossRef]

17. Yu, H.-C.; Kuo, L. Corporate philanthropy strategy and sustainable development goals. Sustainability 2021, 13, 5655. [CrossRef]

18. Krishnan, S.; Gupta, S.; Kaliyan, M.; Kumar, V.; Garza-Reyes, J.A. Assessing the key enablers for Industry 4.0 adoption using MICMAC analysis: A case study. Int. J. Product. Perform. Manag. 2021, 70, 1049-1071. [CrossRef]

19. Fernandes, J.; Reis, J.; Melão, N.; Teixeira, L.; Amorim, M. The role of Industry 4.0 and BPMN in the arise of condition-based and predictive maintenance: A case study in the automotive industry. Appl. Sci. 2021, 11, 3438. [CrossRef] 
20. Silva, F.; Resende, D.; Amorim, M.; Borges, M. A field study on the impacts of implementing concepts and elements of Industry 4.0 in the biopharmaceutical sector. JOItmC 2020, 6, 175. [CrossRef]

21. Lola, I.S.; Bakeev, M. Pilot study of industry 4.0 and digital technology prevalence in Russian manufacturing companies. Manag. Prod. Eng. Rev. 2020, 11, 26-37.

22. Mijatović, M.D.; Uzelac, O.; Stoiljković, A. Effects of human resources management on the manufacturing firm performance: Sustainable development approach. Int. J. Ind. Eng. Manag. 2020, 11, 205-212. [CrossRef]

23. Lorenz, R.; Benninghaus, C.; Friedli, T.; Netland, T.H. Digitization of manufacturing: The role of external search. Int. J. Oper. Manag. 2020, 40, 1129-1152. [CrossRef]

24. James, S.; Shetty, A. An initial model for implementation of industry 4.0 in the high technological manufacturing sector in Southern California. In Proceedings of the ASME International Mechanical Engineering Congress and Exposition, Proceedings (IMECE) 2B, Salt Lake City, UT, USA, 8-14 November 2019; pp. 1-13. [CrossRef]

25. Kumar, P.; Singh, R.K.; Kumar, V. Managing supply chains for sustainable operations in the era of Industry 4.0 and circular economy: Analysis of barriers. Resour. Conserv. Recycl. 2021, 164, 105215. [CrossRef]

26. Singhal, N. An empirical investigation of Industry 4.0 preparedness in India. Vision 2020, 25, 300-311. [CrossRef]

27. Contador, J.C.; Cardoso, W.; Contador, J.L.; Spinola, M.M. Taxonomy of organizational alignment: Implications for data-driven sustainable performance of firms and supply chains. J. Enterp. Inf. Manag. 2021, 34, 343-364. [CrossRef]

28. Baltazar, J.; Reis, J.; Amorim, M. Sustainable economies: Using a macro-economic model to predict how the default rate is affected under economic stress scenarios. Sustain. Futures 2020, 2, 100011. [CrossRef]

29. Frank, A.G.; Dalenogare, L.S.; Ayala, N.F. Industry 4.0 technologies: Implementation patterns in manufacturing companies. Int. J. Prod. Econ. 2019, 210, 15-26. [CrossRef]

30. Mian, S.H.; Salah, B.; Ameen, W.; Moiduddin, K.; Alkhalefah, H. Adapting universities for sustainability education in Industry 4.0: Channel of challenges and opportunities. Sustainability 2020, 12, 6100. [CrossRef]

31. Lepore, D.; Micozzi, A.; Spigarelli, F. Industry 4.0 accelerating sustainable manufacturing in the Covid-19 era: Assessing the readiness and responsiveness of Italian regions. Sustainability 2021, 13, 2670. [CrossRef]

32. Pacchini, A.P.T.; Lucato, W.C.; Facchini, F.; Mummolo, G. The degree of readiness for the implementation of Industry 4.0. Comput. Ind. 2019, 113, 103125. [CrossRef]

33. Lucato, W.C.; Pacchini, A.P.T.; Facchini, F.; Mummolo, G. Model to evaluate the Industry 4.0 readiness degree in Industrial Companies. IFAC-PapersOnLine 2019, 52, 1808-1813. [CrossRef]

34. Basl, J. Pilot study of readiness of Czech companies to implement the principles of Industry 4.0. Manag. Prod. Eng. Rev. 2017, 8, 3-8. [CrossRef]

35. Castelo-Branco, I.; Jesus, F.C.; Oliveira, T. Assessing Industry 4.0 readiness in manufacturing: Evidence for the European Union. Comput. Ind. 2019, 107, 22-32. [CrossRef]

36. Mittal, S.; Khan, M.A.; Romero, D.; Wuest, T. A critical review of smart manufacturing \& Industry 4.0 maturity models: Implications for small and medium-sized enterprises (SMEs). J. Manuf. Syst. 2018, 49, 194-214.

37. Gajsek, B.; Marolt, J.; Rupnik, B.; Lerher, T.; Sternad, M. Using maturity model and discrete-event simulation for industry 4.0 implementation. Int. J. Simul. Model. 2019, 18, 488-499. [CrossRef]

38. Lichtblau, K.; Stich, V.; Bertenrath, R.; Blum, M.; Bleider, M.; Millack, A.; Schmitt, K.; Schmitz, E.; Schröter, M. IMPULS, Industry 4.0 Readiness; VDMA: Aachen/Cologne, Germany, 2015; pp. 1-78.

39. Schuh, G.; Reiner Ander, R.; Gausemeier, J.; ten Hompel, M.; Wahlster, W. Industrie 4.0 Maturity Index: Managing the Digital Transformation of Companies; (acatech STUDY); Herbert Utz Verlag: Munich, Germany, 2017.

40. Sony, M.; Naik, S.S. Ten Lessons for Managers while Implementing Industry 4.0. IEEE Eng. Manag. Rev. 2019, 47, 45-52. [CrossRef]

41. Rajput, S.; Singh, S.P. Industry 4.0-Challenges to implement circular economy. Benchmarking 2019, 28, 1717-1739. [CrossRef]

42. Butt, J. A conceptual model to support digital transformation in manufacturing using an integrated business process management approach. Designs 2020, 4, 17. [CrossRef]

43. Linde, L.; Sjödin, D.; Parida, V.; Gebauer, H. Evaluation of digital business model opportunities: A model for avoiding digitalization traps. Res. Technol. Manag. 2020, 64, 43-53. [CrossRef]

44. Amjad, M.S.; Rafique, M.Z.; Khan, M.A. Leveraging optimized and cleaner production through Industry 4.0. Sustain. Prod. Consum. 2021, 26, 859-871. [CrossRef]

45. Rajput, S.; Singh, S.P. Industry 4.0 Model for circular economy and cleaner production. J. Clean. Prod. 2020, 277, 123853. [CrossRef]

46. Shayganmehr, M.; Kumar, A.; Garza-Reyes, J.A.; Moktadir, M.A. Industry 4.0 enablers for a cleaner production and circular economy within the context of business ethics: A study in a developing country. J. Clean. Prod. 2021, 281, 125280. [CrossRef]

47. Ma, S.; Zhang, Y.; Liu, Y.; Yang, H.; Lv, J.; Ren, S. Data-driven sustainable intelligent manufacturing based on demand response for energy-intensive industries. J. Clean. Prod. 2020, 274, 123155. [CrossRef]

48. Calabrese, A.; Levialdi Ghiron, N.; Tiburzi, L. 'Evolutions' and 'revolutions' in manufacturers' implementation of industry 4.0: A literature review, a multiple case study, and a conceptual model. Prod. Plan. Control. 2021, 32, 213-227. [CrossRef]

49. Pinheiro, P.; Putnik, G.D.; Castro, A.; Castro, H.; Dal Bosco, F.R.; Romero, F. Industry 4.0 and industrial revolutions: An assessment based on complexity. FME Trans. 2019, 47, 831-840. [CrossRef]

50. Lo Bello, L.; Behnam, M.; Pedreiras, P.; Sauter, T. Guest editorial special section on communications in automation-innovation drivers and new trends. IEEE Trans. Industr. Inform. 2017, 13, 841-845. [CrossRef] 
51. Lezoche, M.; Hernandez, J.E.; Alemany Díaz, M.M.E.; Panetto, H.; Kacprzyk, J. Agri-food 4.0: A survey of the supply chains and technologies for the future agriculture. Comput. Ind. 2020, 117, 1-15. [CrossRef]

52. Türkeş, M.C.; Oncioiu, I.; Aslam, H.D.; Marin-Pantelescu, A.; Topor, D.I.; Căpuşneanu, S. Drivers and barriers in using industry 4.0: A perspective of SMEs in Romania. Processes 2019, 7, 153. [CrossRef]

53. Singh, S.; Mahanty, B.; Tiwari, M.K. Model and modelling of inclusive manufacturing system. Int. J. Comput. Integr. Manuf. 2019, 32, 105-123. [CrossRef]

54. Colombo, A.W.; Karnouskos, S.; Yu, X.; Kaynak, O.; Luo, R.C.; Shi, Y.; Leitão, P.; Ribeiro, L.; Haase, J. A 70-Year Industrial Electronics Society Evolution through Industrial Revolutions: The rise and flourishing of Information and Communication Technologies. IEEE Ind. Electron. Mag. 2021, 15, 115-126. [CrossRef]

55. Virmani, N.; Salve, U.R.; Kumar, A.; Luthra, S. Analyzing roadblocks of Industry 4.0 adoption using graph theory and matrix approach. IEEE Trans. Eng. Manag. 2021, 1-10. [CrossRef]

56. De Oliveira Neto, G.C.; Tucci, H.N.P.; Godinho Filho, M.; Lucato, W.C.; Correia, J.M.F. Performance evaluation of occupational health and safety in relation to the COVID-19 fighting practices established by WHO: Survey in multinational industries. Saf. Sci. 2021, 141, 105331. [CrossRef]

57. Vanalle, R.M.; Lucato, W.C.; Ganga, G.M.D.; Alves Filho, A.G. Risk management in the automotive supply chain: An exploratory study in Brazil. Int. J. Prod. Res. 2020, 58, 783-799. [CrossRef]

58. Martins, F.S.; Lucato, W.C.; Vils, L.; Serra, F.A.R. The effects of market and entrepreneurial orientation on the ambidexterity of multinational companies' subsidiaries. Eur. Bus. Rev. 2020, 32, 4-25. [CrossRef]

59. Cao, H.; Yang, X. Auto-configurable Event-Driven Architecture for Smart Manufacturing. In Advances in Production Management Systems. The Path to Intelligent, Collaborative and Sustainable Manufacturing; Lödding, H., Riedel, R., Thoben, K.D., von Cieminski, G., Kiritsis, D., Eds.; Springer: Cham, Switzerland, 2017; Volume 513, pp. 30-38.

60. Satyro, W.C.; Martens, M.L.; Spinola, M.d.M.; Vanalle, R.M.; Lucato, W.C.; De Oliveira Neto, G.C.; Rodrigues Pinto, L.F. Industry 4.0 in Brazil, Ireland and Argentina: Challenges and opportunities. In Proceedings of the International Conference on Computers and Industrial Engineering, Beijing, China, 18-21 October 2019; pp. 1-10.

61. Gomes, M.G.; da Silva, V.H.C.; Rodrigues Pinto, L.F.; Centoamore, P.; Digiesi, S.; Facchini, F.; de Oliveira Neto, G.C. Economic, environmental and social gains of the implementation of artificial intelligence at dam operations toward Industry 4.0 principles. Sustainability 2020, 12, 3604. [CrossRef]

62. Oztemel, E.; Gursev, S. Literature review of Industry 4.0 and related technologies. J. Intell. Manuf. 2020, 31, 127-182. [CrossRef]

63. Gasparetto, W.; Egger, G.; Giusti, A.; Giusti, A.; Ruach, E.; Riedl, M.; Matt, D.T. Intelligent workpiece carrier for distributed data collection and control in manufacturing environments. Procedia Manuf. 2018, 24, 190-195. [CrossRef]

64. Choi, S.S.; Kang, G.; Jung, K.; Kulvatunyou, B.; Morris, K.C. Applications of the factory design and improvement reference activity model. IFIP Adv. Inf. Commun. Technol. APMS 2016, 488, 697-704.

65. Mugarza, I.; Parra, J.; Jacob, E. Software Updates in Safety and Security Co-engineering. In Computer Safety, Reliability, and Security. SAFECOMP; Tonetta, S., Schoitsch, E., Bitsch, F., Eds.; Springer: Cham, Switzerland, 2017; Volume 10489. [CrossRef]

66. Bär, K.; Herbert-Hansen, Z.N.L.; Khalid, W. Considering Industry 4.0 aspects in the supply chain for an SME. Prod. Eng. 2018, 12, 747-758. [CrossRef]

67. Li, L. China's manufacturing locus in 2025: With a comparison of "Made-in-China 2025" and "Industry 4.0". Technol. Forecast. Soc. Chang. 2018, 135, 66-74. [CrossRef]

68. United Nations Environment Programme (UNEP) 1972-2022. International Declaration on Cleaner Production: Implementation Guidelines for Facilitating Organizations. Available online: https:/ / www.unep.org/resources/report/international-declarationcleaner-production-implementation-guidelines (accessed on 15 June 2021).

69. Duflou, J.; Kellens, K. Cleaner Production. In The International Academy for Production Engineering; Laperrière, L., Reinhart, G., Eds.; CIRP Encyclopedia of Production Engineering; Springer: Berlin/Heidelberg, Germany, 2019. [CrossRef]

70. Take Action for the Sustainable Development Goals, 2014. Available online: https:/ /www.un.org/sustainabledevelopment/ sustainable-development-goals/ (accessed on 15 June 2021).

71. Barbier, E.; Burgess, J. The Sustainable Development Goals and the systems approach to sustainability. Economics 2017, 11, 1-23. [CrossRef]

72. Hoosain, M.S.; Paul, B.S.; Ramakrishna, S. The Impact of 4IR digital technologies and circular thinking on the United Nations Sustainable Development Goals. Sustainability 2020, 12, 143. [CrossRef]

73. Chan, D.W.M.; Chan, J.H.L. Developing a performance measurement index (PMI) for target cost contracts in construction: A Delphi study. Constr. Law J. 2012, 28, 590-613.

74. Ślusarczyk, B. Industry 4.0-Are we ready? Pol. J. Manag. Stud. 2018, 17, 232-248. [CrossRef]

75. Contador, J.C.; Satyro, W.C.; Contador, J.L.; Spinola, M.M. Flexibility in the Brazilian Industry 4.0: Challenges and Opportunities. Glob. J. Flex. Syst. Manag. 2020, 21, 15-31. [CrossRef]

76. Bajic, B.; Rikalovic, A.; Suzic, N.; Piuri, V. Industry 4.0 implementation challenges and opportunities: A managerial perspective. IEEE Syst J. 2021, 15, 546-559. [CrossRef]

77. Jamwal, A.; Agrawal, R.; Sharma, M.; Kumar, A.; Kumar, V.; Garza-Reyes, J.A.A. Machine learning applications for sustainable manufacturing: A bibliometric-based review for future research. J. Enterp. Inf. Manag. 2021, 1-31. [CrossRef]

78. Ferrás-Hernández, X. Rethinking Industry 4.0: Is there life beyond manufacturing? Int. J. Bus. Environ. 2020, 11, 404-416. 
79. Kumar, S.; Suhaib, M.; Asjad, M. Analyzing the barriers to industry 4.0 through best-worst method. Int. J. Perform. Eng. 2020, 16, 27-36. [CrossRef]

80. Sjödin, D.R.; Parida, V.; Leksell, M.; Petrovic, A. Smart factory implementation and process innovation: A preliminary maturity model for leveraging digitalization in manufacturing moving to smart factories presents specific challenges that can be addressed through a structured approach focused on people, processes, and technologies. Res. Technol. Manag. 2018, 61, 22-31.

81. Mueller, E.; Chen, X.-L.; Riedel, R. Challenges and Requirements for the application of Industry 4.0: A special insight with the usage of Cyber-Physical System. Chin. J. Mech. Eng. 2017, 30, 1050-1057. [CrossRef]

82. Martinez, F. Process excellence the key for digitalization. Bus. Process Manag. J. 2019, 25, 1716-1733. [CrossRef]

83. Devi, K.S.; Paranitharan, K.P.; Agniveesh, A.I. Interpretive model by analysing the enablers for implementation of Industry 4.0: An ISM approach. Total. Qual. Manag. Bus. Excell. 2020,1-22. [CrossRef]

84. Rybski, C.; Jochem, R. Procedure model to integrate digital elements into lean production systems. Int. J. Qual. Serv. Sci. 2021, 13, $1-15$.

85. Jain, V.; Ajmera, P. Modelling the enablers of Industry 4.0 in the Indian manufacturing industry. Int. J. Product. Perform. Manag. 2020, 1-30. [CrossRef]

86. Bag, S.; Sahu, A.K.; Kilbourn, P.; Pisa, N.; Dhamija, P.; Sahu, A.K. Modeling barriers of digital manufacturing in a circular economy for enhancing sustainability. Int. J. Product. Perform. Manag. 2021, 1-37. [CrossRef]

87. Lu, J.; Ren, L.; Zhang, C.; Rong, D.; Ahmed, R.R.; Streimikis, J. Modified Carroll's pyramid of corporate social responsibility to enhance organizational performance of SMEs industry. J. Clean. Prod. 2020, 271. [CrossRef]

88. de Guimarães, J.C.F.; Severo, E.A.; Jabbour, C.J.C.; de Sousa Jabbour, A.B.L.; Rosa, A.F.P. The journey towards sustainable product development: Why are some manufacturing companies better than others at product innovation? Technovation 2021, 103, 1-15. [CrossRef]

89. Wróblewski, P.; Drożdż, W.; Lewicki, W.; Miązek, P. Methodology for assessing the impact of aperiodic phenomena on the energy balance of propulsion engines in vehicle electromobility systems for given areas. Energies 2021, 14, 2314. [CrossRef]

90. Wróblewski, P.; Drożdż, W.; Lewicki, W.; Dowejko, J. Total cost of ownership and its potential consequences for the development of the hydrogen fuel cell powered vehicle market in Poland. Energies 2021, 14, 2131. [CrossRef]

91. Sony, M.; Antony, J.; Mc Dermott, O.; Garza-Reyes, J.A. An empirical examination of benefits, challenges, and critical success factors of industry 4.0 in manufacturing and service sector. Technol. Soc. 2021, 67, 101754. [CrossRef]

92. Maskuriy, R.; Selamat, A.; Maresova, P.; Krejcar, O.; David, O.O. Industry 4.0 for the construction industry: Review of management perspective. Economies 2019, 7, 68. [CrossRef]

93. Maskuriy, R.; Selamat, A.; Ali, K.N.; Maresova, P.K. Industry 4.0 for the construction industry-How ready is the industry? Appl. Sci. 2019, 9, 2819. [CrossRef]

94. Soares Júnior, G.G.; Satyro, W.C.; Bonilla, S.H.; Contador, J.C.; Barbosa, A.P.; Monken SF de, P.; Martens, M.L.; Fragomeni, M.A. Construction 4.0: Industry 4.0 enabling technologies applied to improve workplace safety in construction. Res. Soc. Dev. 2021, 10, 1-18. [CrossRef]

95. Tripathi, S.; Gupta, M. A holistic model for Global Industry 4.0 readiness assessment. Benchmarking 2021. [CrossRef]

96. Tay, S.I.; Alipal, J.; Lee, T.C. Industry 4.0: Current practice and challenges in Malaysian manufacturing firms. Technol. Soc. 2021, 67, 101749. [CrossRef]

97. Birkel, H.; Müller, J.M. Potentials of industry 4.0 for supply chain management within the triple bottom line of sustainability-A systematic literature review. J. Clean. Prod. 2021, 289, 125612. [CrossRef]

98. Satyro, W.C.; Spinola, M.D.M.; de Almeida, C.M.V.B.; Giannetti, B.F.; Sacomano, J.B.; Contador, J.C.; Contador, J.L. Sustainable industries: Production planning and control as an ally to implement strategy. J. Clean. Prod. 2021, 281, 124781. [CrossRef]

99. Gustavo, J.U., Jr.; Trento, L.R.; de Souza, M.; Pereira, G.M.; de Souza Jabbour, A.B.L.; Ndubisi, N.O.; Jabbour, C.J.C.; Borchardt, M.; Zvirtes, L. Green marketing in supermarkets: Conventional and digitized marketing alternatives to reduce waste. J. Clean. Prod. 2021, 296, 126531. [CrossRef]

100. Sushil. Small steps for a giant leap: Flexible organization. Glob. J. Flex. Syst. Manag. 2017, 18, 273-274. [CrossRef]

101. Sushil. Interpretive multi-criteria ranking of production systems with ordinal weights and transitive dominance relationships. Ann. Oper. Res. 2020, 290, 677-695. [CrossRef]

102. de Paoli, F.M.; de Oliveira Neto, G.C.; Lucato, W.C. Economic and environmental gains resulting from the utilization of the design for the environment (DfE) | [Vantagens econômicas e ambientais resultantes da aplicação do projeto para o meio ambiente (DfE)]. Espacios 2013, 34, 11.

103. Cesar da Silva, P.; Cardoso de Oliveira Neto, G.; Ferreira Correia, J.M.; Pujol Tucci, H.N. Evaluation of economic, environmental and operational performance of the adoption of cleaner production: Survey in large textile industries. J. Clean. Prod. 2021, 278, 123855. [CrossRef] 